\title{
発光ダイオードを用いた超高速紫外線パルス光源の開発と応用
}

\author{
正会員 荒 木 勉（德島大学）
}

\section{Design and Performance of High-speed, Ultra-violet Pulsed Light Source Using a Light Emitting Diode}

Member Tsutomu Araki (Univ. of Tokushima)

KEYWORDS : light emitting diode, ultraviolet light, nanosecond pulse, photodetector, blue LED

\section{1.はじめに}

十ノ秒領域の高速光測定は高分子構造変化検出，エネルギー移 動追跡などに利用できる重要な手法である。そのための装置応答 の校正には時間制御ができるインパルス光源が必要となる。その 光源を青色発光ダイオード（LED）で実現することが本研究の目 的である。一般に, LED パルス光源の特長は(1)安価で供給が安定， (2)外部トリガーが可能, (3)小型, (4)長寿命, (5)低電圧, 低電力の ため安全である．特に応答性については適切な素子と駆動回路を 用いればナノ秒オーダーのパルス光を発生させることができる。 カタログや仕様書記載の推奨回路では，パルス駆動として定格電 流の高々数倍から10倍の電流が注入されている。これに対して筆 者らはLEDに定格電流の100倍以上のピーク電流を注入してパ ルス駆動し，高速の紫外線パルス光を得る方法を提案してき た ${ }^{1,2)}$. しかし高速大電流で青色 LED をパルス駆動したときの光 波形，発光スペクトル，放射束，耐久性などについてはこれまで ほとんど知られていない。また，パルス幅の短縮化が十分でない。 そこで本研究ではこれらを詳細に調査し，その結果をもとに光パ ルス幅の短縮化を図った。また，そのようにして得られた紫外パ ルス光源を用いて，高速光検出器の応答特性を測定した。

\section{2 . 装置と测定方法}

青色 LED は日曲化学工業の NLPB300を用いた，図 1 にLED パルス駆動回路を示寸。ここでは高速スイッチング素子として, アバランシェトランジスタ (ZETEX 社 ZTX415)を使用した。 こ の素子はコレクターエミッタ間に高電圧を印加し, トリガーパル 又(波高 $5 \mathrm{~V}$ ，パルス幅50ns 以上) を入力するとアバランシェ(な だれ)効果が起こり，トランジスタが高速で”ON”状態となる。 こ のとき，コンデンサ $(\mathrm{Cd})$ に充電された電荷が LED を介して放電 され，順方向のパルス電流によって発光する。外部抵抗 $\mathrm{R}$ はパル 又電流の測定用端子（Rの再端の電圧波形をモ二夕する）として 用いるほか, 過大電流制限用として用いている. $\mathrm{R}=10 \Omega$ を挿入す ることによる時定数の増加は高だか $1 \mathrm{~ns}$ となるが, 半值幅が 1 ns 前後となるような極短パルス発光の場合には Rの值を適宜低 減する必要がある.インダク夕 $\mathrm{L}(0.53 \mu \mathrm{H})$ はパルス電流に対し て負のオーバーシュートをつくり, LED 発光時間を短くする役割

本研究は照明学会第 5 回研究・教育成果 [一般研究]による助成課題である。

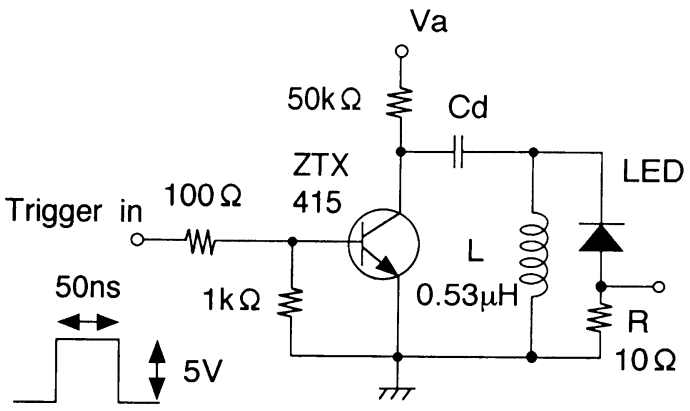

図 1 LED パルス駆動用回路

Fig. 1 Circuit diagram of the pulsed current driver for LED

をはたしている.ここに示した回路の上限電圧は $\mathrm{Va}=350 \mathrm{~V}$, 放電 の繰り返し上限周波数は $100 \mathrm{kHz}$ であるが，今回の基礎実験では 平均電流があまり大きくならないように電压を $\mathrm{Va}=300 \mathrm{~V}$, 周波 数を $20 \mathrm{kHz}$ に設定した。

放射束の測定は, 検出器に光電子增倍管(浜松ホトニクス R5600 -01）を用いて出力電流から算出した。 パルス発光波形はサンプリ ング型光オシロスコープ(浜松ホトニクス OOS-01/VIS 時間分解 能：10ps）を用いて測定した. 発光スペクトルは, 分光器（島津 $\mathrm{MAF}$ 型1200lines $/ \mathrm{mm}$, 焦点距離: $50 \mathrm{~cm}$ ) と光電子増倍管 (浜松木 トニクス製 $1 \mathrm{P} 28$ )の組み合わせで測定した。時間分解発光スぺク トルはストリークカメラ (浜松ホトニクス C-4334, 時間分解能： 5 ps）と分光器（Oriel Multispec 257）を用いて測定した.

\section{3. 結果と考察}

図 2 に青色 LED の発光スペクトルと直流順電流の関係を示

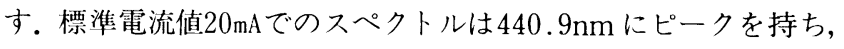
384.3nmにも弱い発光が観測されるが, 順電流が増加するにつれ

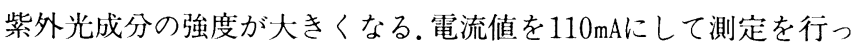
たところ, 発光スペクトルの紫外光成分が可視光成分の強度を超 えていた。この現象は本実験で用いた青色 LED が Zn と Si を同 時添加した $\mathrm{InGaN} / \mathrm{AlGaN}$ ダブルへテロ構造であるために起こ る2). $440.9 \mathrm{~nm}$ の光は, 不純物として添加されている $\mathrm{Zn}$ の不純物 準位に関係する発光であり，この光を青色として利用している. しかし Znの濃度が低いため大電流領域では不純物準位間発光の $440.9 \mathrm{~nm}$ の光は飽和し, 本来のバンド間発光 $(\mathrm{InGaN})$ の紫外光 成分が急激に增加すると考えられる.このことから, 本実験に用 


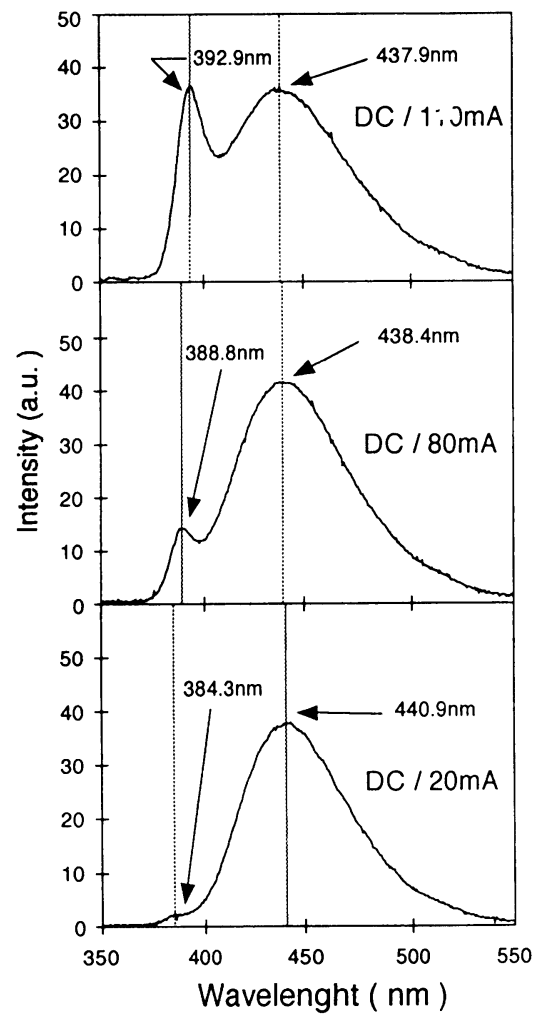

図 2 青色 LED 発光スペクトル

Fig. 2 Emission spectra of blue-LED driven by dc current

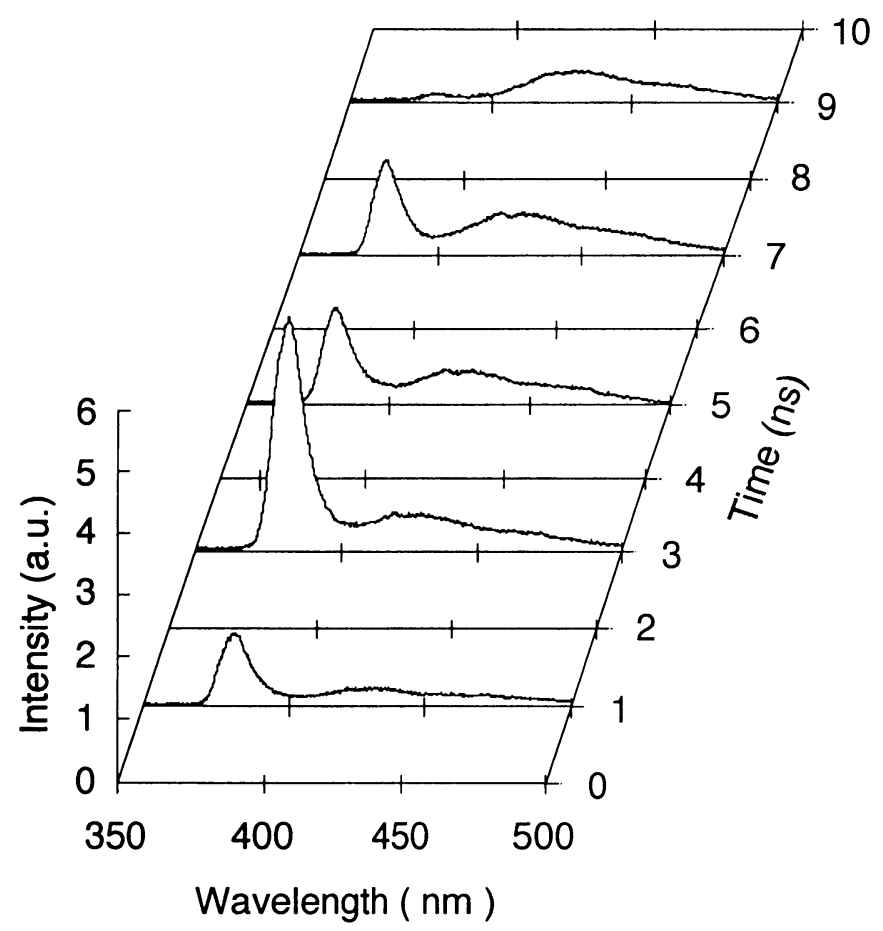

図 3 パルス発光時の青色 LED の時間分解発光スペクトル

Fig. 3 Time-resolved emission spectra of the blue-LED under pulsed opera tion

いた青色 LED に大電流を注入すれば，紫外光源として用いるこ とができることがわかった。

次に LEDをパルス点灯させた場合の時間分解スペクトルを測 定した. 図 3 には, コンデンサ容量 $\mathrm{Cd}=100 \mathrm{pF}$ の場合の発光につ
いて,パルス光の立ち上がり部分から減衰部分へ向かって $2 \mathrm{~ns}$ 間 隔のスペクトルが示されている，パルス電流（ピーク值）は約 2 A である.パルスの立ち上がり部では $380 \mathrm{~nm} に$ にピークを持つ分布 であるが, 時間の経過に伴い $430 \mathrm{~nm}$ にピークがシフトしていくの がわかる. $380 \mathrm{~nm}$ の発光の後に, 不純物準位間 $(\mathrm{Zn})$ の発光が起 こるために，このように電流の注入が終わった後も青色の発光が 続いている．以上から紫外 (UV) 成分が高速応答を示すことが確 認できたので光学つィルターを用いて紫外パルス波形の分離を行 つた，紫外光パルスは立ち上がりの鋭い，裾を引かない波形（半 值全幅： $4.0 \mathrm{~ns}$, ピーク光出力約 $20 \mathrm{~mW}$ ) であった。一方，可視光 パルスはブロードな波形（半值全幅：6.4ns）であった。耐久試験 として $20 \mathrm{kHz}$ の繰り返し数でパルス点灯を継続させたところ, 発 光回数にして $10^{10}$ 回まで一定の放射束を維持した.

パルス光源として利用するのであれば，パルス幅は短く，放射 束は大きいことが理想である。しかし四 1 に示す回路ではアバラ ンシェトランジス夕の耐圧によって印加電圧が制限されるため, パルス幅を $1 \mathrm{~ns}$ にまで短縮する目的で Cd を減少させた場合，十 分な光出力が得られない.そこでアバランシェトランジス夕の直 列接続による $\mathrm{Va}$ 許容值の増大をはかった。同時に， $\mathrm{R}=0, \mathrm{~L}=$ $0.25 \mu \mathrm{H}$ に素子值を修正し，パルスの短縮化をはかった。図4に $\mathrm{Va}=600 \mathrm{~V}$ に設定し， Cd を変化させた場合の UV 光パルス波形 例を示す。リンギングやテイリングの無いパルス発光が得られて いる．この回路では，最小 $1 \mathrm{~ns}$ のパルス幅を持つ光が得られた. また, 幅 $4 \mathrm{~ns}$ のパルス $(\mathrm{Cd}=40 \mathrm{pF})$ では $170 \mathrm{~mW}$ の出力が得られ， 回路の改良によって 8 倍の強度の紫外パルス光が発生できた.

このようにして得られた短時間パルス光を，光電子増倍管の応 答測定に応用した。そのために同じ LED パルス光源回路を $2 つ$ 製作した。それぞれの発光夕イミングをずらせ，光パルスを半透 鏡を用いて重ね合わせるとぺアーパルスができる．2つのパルス の間隔は電気的に制御できる。困 5 に高速の光電子増倍管（浜松 ホトニクス R5600) と汎用の光電子増倍管 (同 1 P28) の応答を示 す．R5600は $1 \mathrm{P} 28$ に比べて高速応答であることが出力バルス波 形からわかった。

以上，市販の発光ダイオードの高速大電流パルス駆動に対する

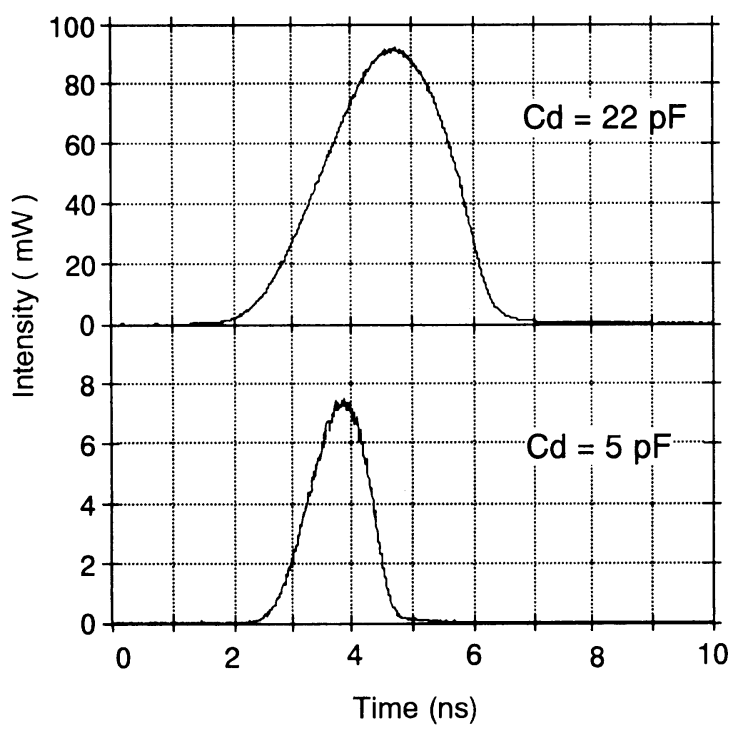

园 4 コンデンサ容量 Cd 值変化による青色 LED の紫外光成分のパルス波形. アバランシェトランジスタは 2 段直列接続, $V a=600 \mathrm{~V}$

Fig. 4 The typical wave forms of UV-light component emitted from the blue LED under $\mathrm{Va}=600 \mathrm{~V}$ 


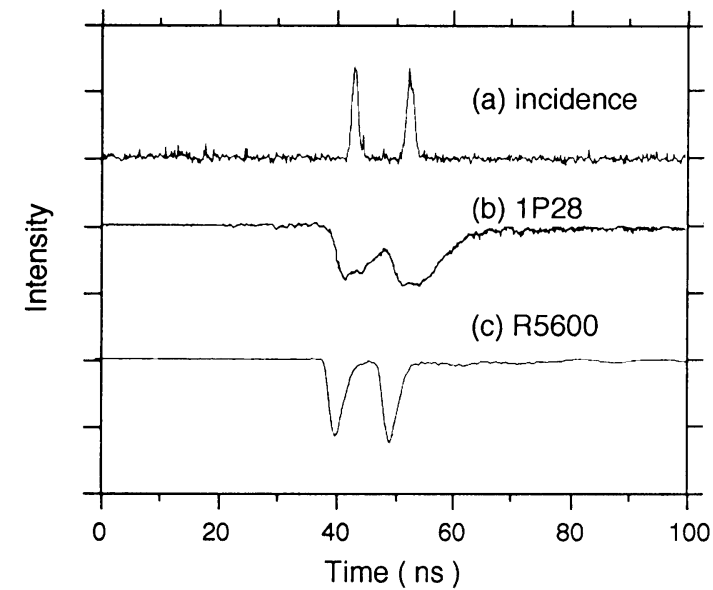

图 5 ペアー光パルス対する光電子増倍管の出力波形

(a)入射波形，(b) 1 P28（沉用サイドウィンドタイプ），(c)R-5600（高速 タイプ)

Fig. 5 Comparison of output signal waveforms between the (b) conventional and (c) fast response photomultiplier tube for (a) the incidence of pair pulse light

忘答性, 耐久性, 放射束の評価を行った。本研究ではアバランシ エトランジスタをスイッチング素子として用いることで，十ノ秒 のパルス光を発生させることができた，青色 LED は電流の増加 に伴って発光スペクトルが大きく変化し, 大電流領域では紫外に
発光があらわれることが確認された。また，パルス電流注入回路 を工夫することでパルス幅を増加させずに光出力を增加させるこ とができた。

\section{参 考 文 献}

(1) T. Araki and H. Misawa : "Light emitting diode-based nanosecond ultraviolet light source for fluorescence lifetime measurements," Rev. Sci. Instrum, 66-12, pp. 5469-5472 (1995)

（2）藤澤, 荒木：「青色 LED を用いたナノ秒紫外パルス光源」, 第56回忍用物理学会学術講演会, p.794（1995）

（3）中村修二：“InGaN/AlGaN 発光ダイオードの現状と性能 向上, ”光学, 23-11, pp.701-708 (1994)

\section{成果の発表}

1) T. Araki, Y. Fujisawa and M. Hashimoto : An ultraviolet nanosecond light pulse generator using a light emitting diode for test of photodetectors, Rev. Sci. Instrum., 683 (1997 in press)

2 ) 藤沢泰立, 橋本 守, 荒木 勉: 発光ダイオードの高速パ ルス電流に対与る応答特性, 照学誌（査読中）

徳島大学工学部機械工学科,

(現) 大阪大学基礎工学部機械工学科, 